\title{
Interaction of Biochar Type and Rhizobia Inoculation Increases the Growth and Biological Nitrogen Fixation of Robinia pseudoacacia Seedlings
}

\author{
Qiaoyu Sun ${ }^{1}$, Yong Liu ${ }^{2}$, Hongbin Liu ${ }^{1}$ and R. Kasten Dumroese ${ }^{3, *(1)}$ \\ 1 Key Laboratory of Non-Point Source Pollution Control, Ministry of Agriculture, \\ Institute of Agricultural Resources and Regional Planning, Chinese Academy of Agricultural Sciences, \\ No. 12 Zhongguancun South Street, Haidian District, Beijing 10081, China; sunqy201306@163.com (Q.S.); \\ liuhongbin@caas.cn (H.L.) \\ 2 Key Laboratory for Silviculture and Conservation, Ministry of Education, Beijing Forestry University, \\ No. 35 Tsinghua East Road, Haidian District, Beijing 100083, China; lyong@bjfu.cn \\ 3 US Department of Agriculture, Forest Service, Rocky Mountain Research Station, 1221 South Main Street, \\ Moscow, ID 83843, USA \\ * Correspondence: kas.dumroese@usda.gov; Tel.: +1-208-883-2324; Fax: +1-208-882-3915
}

Received: 29 May 2020; Accepted: 23 June 2020; Published: 26 June 2020

\begin{abstract}
Adding biochar to soil can change soil properties and subsequently affect plant growth, but this effect can vary because of different feedstocks and methods (e.g., pyrolysis or gasification) used to create the biochar. Growth and biological nitrogen fixation (BNF) of leguminous plants can be improved with rhizobia inoculation that fosters nodule development. Thus, this factorial greenhouse study examined the effects of two types of biochar (i.e., pyrolysis and gasification) added at a rate of $5 \%(v: v)$ to a peat-based growth substrate and rhizobia inoculation (yes or no) on Robinia pseudoacacia (black locust) seedlings supplied with ${ }^{15} \mathrm{NH}_{4}{ }^{15} \mathrm{NO}_{3}$. Seedling and nodule growth, nitrogen $(\mathrm{N})$ content, and $\delta^{15} \mathrm{~N} \times 1000$ were evaluated after 3 months. While addition of biochar without inoculation had no effect on seedling growth, inoculation with rhizobia increased seedling growth, $\mathrm{BNF}$, and $\mathrm{N}$ status. Inoculated seedlings had reduced $\delta^{15} \mathrm{~N}$, indicating that $\mathrm{N}$ provided via fertilization was being diluted by $\mathrm{N}$ additions through BNF. Biochar type and inoculation interacted to affect seedling growth. Combining inoculation with either biochar type increased seedling leaf, stem, and total biomass, whereas gasifier biochar and inoculation improved all seedling growth variables and nodule biomass.
\end{abstract}

Keywords: pyrolysis biochar; gasification biochar; black locust; rhizobium; isotopic nitrogen

\section{Introduction}

Global forest restoration and afforestation have the potential to be major ways to mitigate climate change effects [1,2]. Establishing more trees on the landscape can restore some degraded forests and thereby maintain or improve forest functions [3], such as carbon sequestration [4], biodiversity [5], social sustainability [6], and resilience to climate change [7,8]. Lack of natural regeneration, however, requires planting seedlings [9], and the need for high quality, nursery-grown seedlings to meet global needs is immense $[10,11]$. In particular, seedlings must be able to readily grow on harsh sites, especially those that are droughty or degraded, as the need for reforestation or afforestation on these types of sites is becoming more common [12].

Symbiotic root microorganisms such as mycorrhizae and rhizobia can improve tree establishment, especially on droughty sites or where soil has been severely degraded, such as mining sites [13-15]. Rhizobia, well-known soil microorganisms that colonize the roots of non-leguminous plants and infect 
the roots of leguminous plants [16], can increase nodulation and biological nitrogen (N) fixation (BNF), which subsequently can improve plant survival and outplanting performance [16-21]. Compared to non-inoculated plants, those inoculated with rhizobia had more growth under field and nursery conditions $[16,20,22,23]$. Thus, rhizobia inoculation during nursery production has the potential to improve seedling quality and thereby alleviate limiting factors on the outplanting site (identified by implementing the Target Plant Concept; [24]) that threaten reforestation success, especially poor soil $\mathrm{N}$ availability. Rhizobia improve the ability of seedlings to adapt to environmental and climatic change. Rhizobia inoculation improved the resistance of plants to environmental stresses in arid areas [25]. Under an elevated $\mathrm{CO}_{2}$ level, similar to that expected with climate change, symbiotic microbes persisted and increased plant growth and photosynthesis [26], as well as enhanced nodule development, plant nutrition, and $\mathrm{N}_{2}$ fixation rates [27].

Biochar is a stable, recalcitrant, and carbon-rich product, used as a soil amendment in agriculture and forest systems [28-30]. Site preparation and seedling quality may also be improved by incorporating biochar into the reforestation program [31]. In forest systems, converting forest residues to biochar, rather than disposing of them through piling and burning, a practice that can damage soils, can instead maintain soil quality and potential forest productivity [31]. This biochar, added to soil, can increase soil surface area and porosity and decrease bulk density, thus improving hydraulic conductivity and water retention capacity [32], soil fertility [33], nutrient availability [32], and biological properties [34-37].

Biochar as an amendment to, or as a replacement for, Sphagnum peatmoss or other soilless media components (e.g., vermiculite) has shown positive effects on seedling propagation, either to the seedlings directly or toward a more sustainable use of resources (e.g., reduced irrigation needs) in soilless growing environments [38-43].

Biochar is produced by thermal decomposition of biomass through different technologies, such as pyrolysis and gasification, both of which combust biomass in a very low oxygen environment. Pyrolysis occurs at 300 to $700{ }^{\circ} \mathrm{C}$, with biochar, gas and bio-oil as final products, whereas gasification occurs at more than $700{ }^{\circ} \mathrm{C}$, yielding more energy, more ash, and less biochar than pyrolysis [44]. The biochars from these two processes have physical and chemical properties that influence their suitability as a soil amendment in agricultural production [44]. Applying biochar from pyrolysis to soil has been reported to improve crop growth and yield, attributed mostly to improvements in soil nutrient availability and microbial activity $[35,36,45]$. Hansen et al. [46] reported that adding biochar from gasification increased soil organic carbon, cation exchange capacity, and $\mathrm{pH}$. Gasification biochar has potential to accelerate crop productivity by increasing soil water retention and enhancing root growth [47]. Currently, most research has focused on the effects on soil properties and/or plant growth caused by biochar from either pyrolysis or gasification [36,47], but few studies have compared the two types of biochar [44].

Although many studies have investigated the advantages of biochar application in crop production (e.g., maize (Zea mays L.), groundnut (Arachis hypogaea L.), and soybean (Glycine max (L.) Merr.)), only a few studies have focused on its application to produce tree seedlings for forest restoration (e.g., Japanese zelkova (Zelkova serrata (Thunb.) Makino), ponderosa pine (Pinus ponderosa Lawson and C. Lawson), interior Douglas-fir (Pseudotsuga menziesii (Mirb.) Franco var. glauca (Beissn.) Franco), Masson's pine (Pinus massoniana (Lamb.)), and Chinese fir (Cunninghamia lanceolata (Lamb.) Hook.)) [43,48-51]. Following that pattern, only a few studies with agricultural crops have examined the interaction of rhizobia inoculation with biochar amendment. They do, however, report a synergistic effect of rhizobia and biochar addition on growth and physiology of maize, groundnut [16,52] and soybean nodulation. To the best of our knowledge, this is the first effort to look at the interaction of biochar and rhizobia inoculation on a forest tree species.

For this study, we chose the legume black locust (Robinia pseudoacacia L.), a native tree to the eastern United States that is now widely naturalized across the temperate regions of Europe, Asia, Australia, New Zealand, and Africa [53]. It is commonly grown in nurseries that produce seedlings in containers because it is an important species for afforestation on abandoned farmlands, erosion control, and soil stabilization on disturbed sites $[54,55]$. Our overall objective was to assess the effects 
of biochar produced by two methods (pyrolysis and gasification) and added to a peat substrate with or without rhizobia inoculation on the subsequent growth and $\mathrm{N}$ dynamics of black locust seedlings.

\section{Materials and Methods}

\subsection{Experimental Design and Seed Sowing}

To test our hypotheses, we designed a two-factor, completely randomized experiment with 2 biochar types (pyrolysis and gasification) and none as control and 2 rhizobia inoculation levels (yes or no). Black locust seeds (collected in 2012 in Kentucky, USA; Lawyer Nursery Inc., Plains, MT, USA) were submerged in $70{ }^{\circ} \mathrm{C}$ water (the heat source was removed immediately) and left for $24 \mathrm{~h}$ to cool to ambient temperature (seeds:water $=15 \mathrm{~g}: 500 \mathrm{~mL}$ ). Black locust seeds were inoculated with appropriate rhizobia (the proprietary inoculant contained 2 strains; Plant Probiotics Company, Indianapolis, IN, USA) (rhizobia:seeds $=1 \mathrm{~g}: 100 \mathrm{~g} ; 3 \times 10^{8}$ colony forming units $/ 100 \mathrm{~g}$ of seeds) before sowing [21]. Inoculated black locust seeds were sowed into Ray Leach SC10RA containers (volume $158 \mathrm{~cm}^{3}$; density 528 seedling $/ \mathrm{m}^{2}$; diameter $3.8 \mathrm{~cm} \times$ length $18 \mathrm{~cm}$; Stuewe and Sons, Inc., Tangent, OR, USA). Containers were filled by hand with 3:1 Sphagnum peatmoss:vermiculite (v:v) (Forestry \#1, Sun Gro Horticulture Ltd., Agawam, MA, USA) amended with 5\% biochar on a volume basis. We choose this rate because the literature shows application rates of $5 \%$ to $40 \%$ have shown benefits to seedling growth in containers (e.g., [43,56]) but rates above $25 \%$ have also been shown to be deleterious (e.g., [50]). Thus, we added biochar at $5 \%$ v:v to avoid potential negative effects of elevated levels of biochar while still comparing biochar type. The 2 types of biochar tested in this study were pyrolysis (nutshells, Cool Planet Company, Greenwood Village, CO, USA) and gasification (forest mill residue, Tucker Engineering Associates, Locust, NC, USA). The characteristics of pyrolysis- and gasification-based biochar are shown in Table 1. Both biochars were passed through a $2 \mathrm{~mm}$ mesh for uniformity. The experiment was conducted in a fully-controlled greenhouse at the USDA Forest Service, Rocky Mountain Research Station in Moscow, ID, USA $\left(46.72^{\circ} \mathrm{N}, 117.00^{\circ} \mathrm{W} ; 798 \mathrm{~m}\right.$ elevation). The greenhouse maintained a temperature of $28^{\circ} \mathrm{C}$ day $/ 16^{\circ} \mathrm{C}$ night, and 16 -h photoperiod with light intensity of 700-2300 Lux.

Table 1. The characteristics of biochar.

\begin{tabular}{cccccc}
\hline Biochar Type & $\mathbf{p H}$ & Density $(\mathrm{g} / \mathbf{m L})$ & Pore Volume $\mathbf{( \mathbf { c m } ^ { 3 } / \mathbf { g } )}$ & $\mathbf{C ~ ( \% )}$ & $\mathbf{N}(\mathbf{\%})$ \\
\hline Pyrolysis & 7.1 & 0.53 & 0.09 & 76.4 & 0.56 \\
Gasification & 10.2 & 0.17 & 0.016 & 91.5 & 0.89 \\
\hline
\end{tabular}

Note: Pyrolysis biochar characteristics are from Cool Planet Company, Greenwood Village, CO, USA. Gasification biochar characteristics are from Anderson et al. [44].

\subsection{Seedling Culture}

Eight replications were considered for each treatment (i.e., biochar type and inoculation combination) therefore 48 containers were planted in total. All containers were misted daily until emergence (about 10 days). Subsequently, all containers were irrigated when the amount of water in the substrate, determined gravimetrically, was $\leq 75 \%$ of the total water capacity of the substrate [57]. Water was added to replenish the media to $100 \%$ to avoid leaching of nutrients. Fertilization started 14 days after planting (DAP). Once each week, when irrigation was required, we provided each seedling with $2 \mathrm{mg} \mathrm{N}$ ( $20 \mathrm{mg} \mathrm{N}$ total during a 10-week growing cycle). This was achieved via application of $15 \mathrm{~mL}$ of nutrient solution containing $\mathrm{NH}_{4} \mathrm{NO}_{3}, 75 \% \mathrm{H}_{3} \mathrm{PO}_{4}, \mathrm{KH}_{2} \mathrm{PO}_{4}, \mathrm{CaCl}_{2}$, and $\mathrm{MgSO}_{4}$ at $4.89,1.95$, 2.65, 3.78, and $9.95 \times 10^{-3} \mathrm{~mol} / \mathrm{L}$. Additionally, micronutrients (sulfur (S), $13 \%$; manganese (Mn), $8 \%$; iron $(\mathrm{Fe}), 7.5 \%$; copper $(\mathrm{Cu}), 2.3 \%$; boron $(\mathrm{B}), 1.35 \%$; molybdenum $(\mathrm{Mo}), 0.04 \%$; Peters Professional ${ }^{\circledR}$ S.T.E.M. ${ }^{\text {TM }}$, the Scotts Company, Marysville, OH, USA) and Sprint 330 (chelated iron $(\mathrm{Fe}), 10 \% \mathrm{Fe}$, Becker Underwood, Inc., Ames, IA, USA) were added at $15 \mathrm{mg} / \mathrm{L}$ and $20 \mathrm{mg} / \mathrm{L}$, respectively. If the $15 \mathrm{~mL}$ of nutrient solution was insufficient to return the substrate to $100 \%$ container capacity, additional 
plain water was added. We supplied $\mathrm{N}$ as $\mathrm{NH}_{4} \mathrm{NO}_{3}$ amended ${ }^{15} \mathrm{NH}_{4}{ }^{15} \mathrm{NO}_{3}$ enriched to $98 \%{ }^{15} \mathrm{~N}$ (Sigma Aldrich, St. Louis, MO, USA) to measure differential dilution of absorbed ${ }^{15} \mathrm{~N}$-labeled fertilizer through N-fixation by rhizobia [58]. The ratio of ${ }^{15} \mathrm{~N}:{ }^{14} \mathrm{~N}$ was $0.0037: 1$. Seedlings were re-inoculated to ensure inoculation after $28 \mathrm{DAP}$ by adding $5 \mathrm{~mL}$ inoculant solution (rhizobia:water $=0.5 \mathrm{~g}: 1.25 \mathrm{~L}$ ) to each seedling. We rotated trays every 14 days to minimize edge effects.

After 3 months of growing, we measured the height and the root-collar diameter (RCD) on the 8 seedlings per biochar type $\times$ inoculation combination and separated them into leaves, stems, roots, and nodules. To count the nodules, the root systems were gently washed and separated. All samples were dried for $72 \mathrm{~h}$ at $65{ }^{\circ} \mathrm{C}$ to determine biomass. Within each treatment, we randomly paired 2 seedlings and mixed each of their tissue types to generate 4 replications for ${ }^{14} \mathrm{~N}$ and ${ }^{15} \mathrm{~N}$ analysis. The concentration of ${ }^{15} \mathrm{~N}$ and ${ }^{14} \mathrm{~N}$ in each tissue of seedlings was determined using a continuous flow isotope ratio mass spectrometer (Finnigan Delta PlusXP, Thermo Fisher Scientific, Breman, Germany) at the Washington State University Stable Isotope Core Laboratory (Pullman, WA, USA). N isotope ratio $\left(\delta^{15} \mathrm{~N}\right)$ was expressed as:

$$
\delta^{15} \mathrm{~N}=\left(\left({ }^{15} \mathrm{~N} \text { sample } /{ }^{14} \mathrm{~N} \text { sample }\right) /\left({ }^{15} \mathrm{~N} \text { air } /{ }^{14} \mathrm{~N} \text { air }\right)-1\right) \times 1000
$$

\subsection{Statistical Analyses}

Analysis of variance (two-way ANOVA) was performed to examine the effects of independent variables, (biochar type and inoculation) and their interaction on the dependent variables seedling height $(\mathrm{cm}), \mathrm{RCD}(\mathrm{mm})$, biomass $(\mathrm{g})$ of leaves, stem, root, nodule, and total plant, nodule number with 8 replications, and $\mathrm{N}$ content $(\mathrm{mg})$ and isotopic $\mathrm{N}\left(\delta^{15} \mathrm{~N} \times 1000\right)$ with 4 replications (SPSS Inc., Chicago, IL, USA). Data were log-transformed to meet the required assumptions for analysis (noted in tables and figures where applicable) when assumptions for equal variances and normality were not met. Significant treatment effects were determined using Duncan's tests. Results were considered significant at $\alpha=0.05$. Visualizations for the robust presentation and comparison of relative values were created using SigmaPlot (version 12.5; Systat Software, San Jose, CA, USA).

\section{Results}

\subsection{Plant Growth}

Biochar type and inoculation significantly interacted to affect height, RCD, and leaf, stem, root, nodule, and total biomass of seedlings (Table 2). For all treatments, the combination of biochar from gasification plus inoculation yielded the greatest height $(42.2 \mathrm{~cm}), \operatorname{RCD}(3.92 \mathrm{~mm})$, and leaf $(1.95 \mathrm{~g})$, stem $(0.63 \mathrm{~g})$, root $(0.49 \mathrm{~g})$, nodule $(0.34 \mathrm{~g})$, and total $(3.07 \mathrm{~g})$ plant biomass after 3 months growing in the greenhouse (Figure 1). These seedlings had significantly more height (17-77\%) and leaf (18-277\%), root $(51-142 \%)$, nodule (98-1103\%), and total plant (22-175\%) biomass than the other treatments, as well as significantly more RCD (5-21\%), and stem biomass (18-113\%) except for inoculated seedlings grown with biochar from pyrolysis (Figure 1). Biochar type had no effect on non-inoculated seedling height, RCD, or the biomass of leaf, stem, and total plant biomass, whereas when combined with inoculation, biochar from gasification yielded seedlings with significantly more height, root, nodule, and total plant biomass than its pyrolysis and control cohorts. Inoculation alone significantly increased all seedling morphological attributes (Table 2) such as height $(44 \%)$, RCD $(19 \%)$, and leaf $(147 \%)$, stem $(80 \%)$, root $(65 \%)$, nodule $(267 \%)$, and total $(123 \%)$ biomass. 
Table 2. $p$-Values for final black locust seedling morphological characteristics.

\begin{tabular}{cccccccc}
\hline \multirow{2}{*}{$\begin{array}{c}\text { Independent } \\
\text { Variables }\end{array}$} & \multirow{2}{*}{$\begin{array}{c}\text { Height } \\
(\mathbf{c m})\end{array}$} & \multirow{2}{*}{$\begin{array}{c}\text { Root-Collar } \\
\text { Diameter }(\mathbf{m m})\end{array}$} & Leaves & Stem & Root & Nodule & Total \\
\hline Biochar type (B) & 0.001 & 0.933 & $<0.0001$ & 0.043 & 0.001 & $<0.0001$ & $<0.0001$ \\
Inoculation (I) & $<0.0001$ & $<0.0001$ & $<0.0001$ & $<0.0001$ & $<0.0001$ & $<0.0001$ & $<0.0001$ \\
$\mathrm{~B} \times \mathrm{I}$ & 0.001 & 0.038 & 0.011 & 0.004 & 0.004 & $<0.0001$ & 0.001 \\
\hline
\end{tabular}

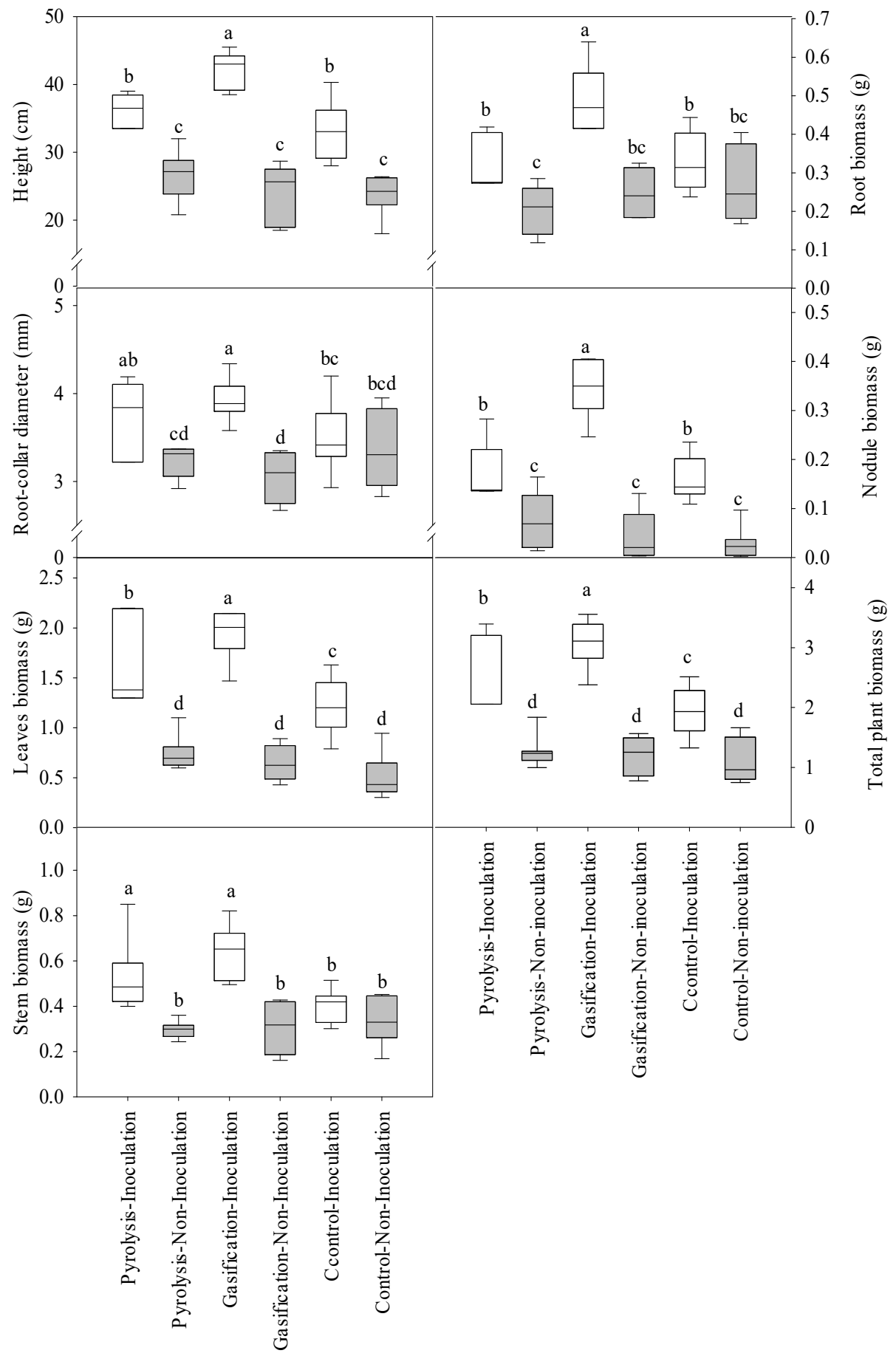

Figure 1. The interaction effect of inoculation $\times$ biochar type on height, root-collar diameter, and leaf, stem, root, nodule, and total biomass of black locust seedlings. Different letters indicate significant differences for biochar type $\times$ inoculation treatments. 


\subsection{Nitrogen Absorption}

Biochar type and inoculation significantly interacted to affect the $\mathrm{N}$ content of leaves and stems (Table 3). Combining inoculation with biochar from gasification or biochar from pyrolysis yielded similar results for leaf $\mathrm{N}$ content $(68.45 \mathrm{~g} / \mathrm{kg})$ and stem $\mathrm{N}$ content $(10.61 \mathrm{~g} / \mathrm{kg})$, that were significantly greater (13-712\% for leaf and $12-308 \%$ for stem N) than in all other treatments (Figure 2a). Compared to non-inoculation treatments, inoculation alone significantly increased leaf (253\%), stem (173\%), and root $(112 \%) \mathrm{N}$ content whereas biochar without inoculation had no effect on tissue $\mathrm{N}$ content. Inoculated seedlings grown with biochar had enhanced tissue $\mathrm{N}$ contents when compared with control seedlings.

Table 3. $p$-Values for final black locust seedling nitrogen content and $\delta^{15} \mathrm{~N} \times 1000$.

\begin{tabular}{ccccccc}
\hline \multirow{2}{*}{$\begin{array}{c}\text { Independent } \\
\text { Variables }\end{array}$} & \multicolumn{2}{c}{ Nitrogen Content $(\mathrm{g} / \mathbf{k g})$} & \multicolumn{3}{c}{$\boldsymbol{\delta}^{\mathbf{1 5}} \mathbf{N} \times \mathbf{1 0 0 0}$} \\
\cline { 2 - 7 } & Leaves & Stem & Root & Leaves & Stem & Root \\
\hline Biochar types (B) & 0.001 & 0.003 & 0.030 & 0.003 & $<0.0001$ & $0.004^{\mathrm{z}}$ \\
Inoculation (I) & $<0.0001$ & $<0.0001$ & $<0.0001$ & $<0.0001$ & $<0.0001$ & $<0.0001$ \\
$\mathrm{~B} \times \mathrm{I}$ & 0.041 & 0.018 & 0.058 & 0.040 & 0.057 & $0.064^{\mathrm{z}}$ \\
\hline
\end{tabular}

Note: ${ }^{z} p$ value represents log-transformed data.

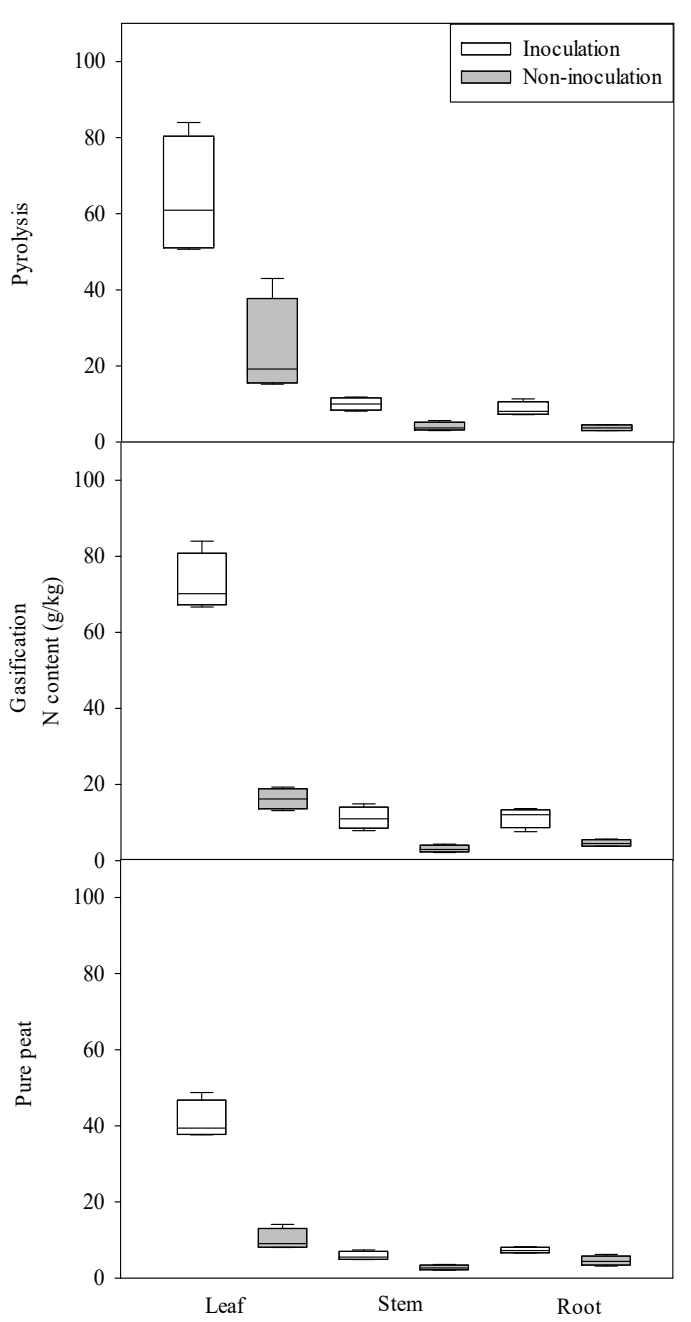

(a)

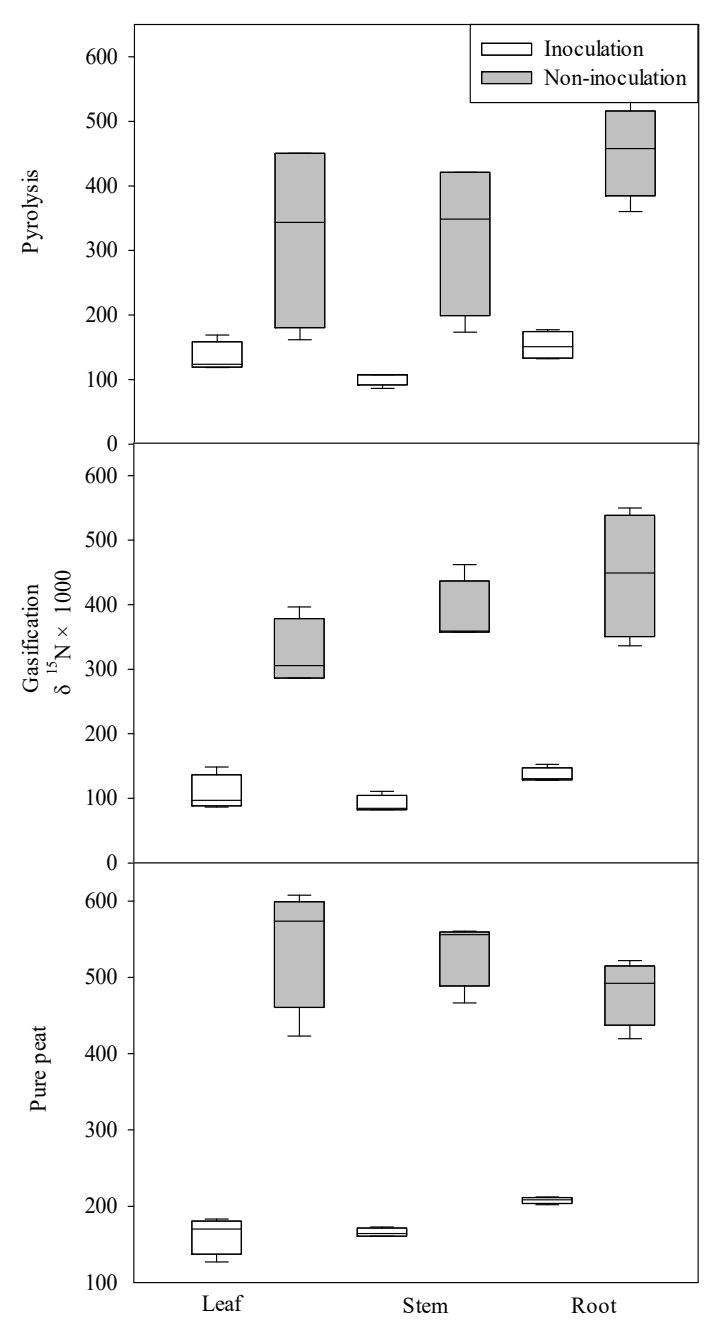

(b)

Figure 2. Nitrogen content $(\mathbf{a})$ and stable nitrogen isotope ratio $\left(\delta^{15} \mathrm{~N} \times 1000\right)(\mathbf{b})$ in different tissue types of black locust seedlings for 2 types of biochar and a control and 2 levels of rhizobia inoculation. 
The value of ${ }^{15} \mathrm{~N}$ in leaves was significantly affected by the interaction of biochar type and inoculation (Table 3). While inoculation always decreased leaf, stem, and root $\delta^{15} \mathrm{~N}$ compared to non-inoculated seedlings (Figure 2b), leaf $\delta^{15} \mathrm{~N}$ of seedlings grown with biochar from gasification and inoculated had significantly lower $\delta^{15} \mathrm{~N}$ than their inoculated cohorts. Not surprisingly, inoculation alone significantly affected $\delta^{15} \mathrm{~N}$ of seedling leaves, stems, and roots (Table 3). When comparing biochar types without inoculation, seedlings grown with biochar from pyrolysis and gasification had similar leaf and stem $\delta^{15} \mathrm{~N}$ that was significantly lower than values observed for control seedlings. When inoculated, control seedlings had significantly higher root $\delta^{15} \mathrm{~N}$ than their biochar-treated cohorts.

\section{Discussion}

The benefits of combining $\mathrm{N}$ fertilization and rhizobia inoculation to black locust seedling growth, in containers in a greenhouse, were recently reported by Zhang et al. [21]. They found $\mathrm{N}$ form (i.e., inorganic or organic) applied at a rate of $2 \mathrm{mg} \mathrm{N} /$ plant during a 12-week growing cycle was not a significant factor. We also obtained acceptable seedling growth using $\mathrm{NH}_{4} \mathrm{NO}_{3}$ applied at $2 \mathrm{mg} \mathrm{N} /$ plant during our 10-week growing cycle. Thus, we believe that this $\mathrm{N}$ supply rate provides an appropriate baseline for evaluating biochar effects on seedling growth and rhizobia abundance and activity.

The influence of biochar on plant growth has been studied in soil and soilless growth media. In soil systems, researchers have reported that biochar addition can increase plant growth $[35,36,59]$. Improved growth may be a response to enhanced soil nutrient availability [60] and/or increased soil surface area, porosity, cation exchange capacity, and/or microbiota activities [16,61]. Improvement in growth may also be a function of reduced physiological stress caused by pathogens [62].

In soilless growth media, work with woody plants has shown that biochar rate affects plant growth. For ponderosa pine, Matt et al. [43] report neutral effects on seedling growth up to $45 \%$ (v:v) pyrolytic biochar in a 3:1:1 ratio of peat, perlite, and vermiculite growing medium, whereas Dumroese et al. [49] report neutral and deleterious effects on growth when pyrolytic biochar was $\leq 25 \%$ and $\geq 50 \%$ (v:v), respectively, in a peatmoss medium. Pelletizing pyrolytic biochar by combining it with wood flour reduced ponderosa pine growth, even at the lowest amount tested in a peatmoss medium $(25 \%$; v:v) [49]. Sarauer and Coleman [50] state that biochar applied at $25 \%$ or $50 \%$ by volume progressively impeded Douglas-fir growth and seedling photosynthetic rate. Biochar can be substituted for growing medium by $20 \%(v: v)$ with container Japanese zelkova seedlings [48]. In our study, we noted that $5 \%$ (v:v) biochar had no effect on seedling growth.

Promotion of legume plant growth through rhizobia inoculation has been achieved for species such as soybean [59], koa (Acacia koa A. Gray) [20], and groundnut [52], as well as for some non-legumes, such as wheat [63] and maize [16], suggesting that the inoculation response on seedling growth is not plant species dependent. In our study, inoculation resulted in more nodule biomass and more seedling growth than that observed in non-inoculated plants, similar to the results of Zhang et al. [21]. Moreover, inoculation increased plant $\mathrm{N}$ content in our seedlings, similar to what has been reported by Jayakumar and Tan [23], Dumroese et al. [20], and Zhang et al. [21]. This enhanced N status supports increased photosynthesis, leading to the additional growth [16,52].

In addition to greater nodule biomass, our inoculated seedlings had reduced $\delta^{15} \mathrm{~N}$ in all tissues relative to the non-inoculated seedlings, revealing that dilution of fertilizer-supplied isotopic $\mathrm{N}$ was occurring because of additions of BNF within the nodules, similar to the results for several species (grain legumes [64]; grain legumes [58]; lentils [65]; and black locust [21]).

In our study, combining the addition of pyrolytic biochar with inoculation sometimes had a synergistic effect on seedling growth compared to those only inoculated, whereas addition of gasifier biochar always had a synergistic effect (Figure 1). An improved growth of seedlings provided by a combination of biochar and inoculation with microorganisms has been noted for maize [16], soybean [66], groundnut [52], and neem (Melia azedarach L. [67]). Inoculation and subsequent BNF within nodules dilute the proportion of $\mathrm{N}$ supplied by fertilization (i.e., increases $\mathrm{N}$ content within the plants). Interestingly, the root $\delta^{15} \mathrm{~N}$ of seedlings cultivated with biochar was higher than the $\delta^{15} \mathrm{~N}$ leaf 
and stem values (Figure 2), suggesting that $\mathrm{N}$ provided by the fertilizer and absorbed from the soil accumulated more in the roots of inoculated seedlings, whereas in non-inoculated seedlings it was more readily transferred to the aerial portions of the seedlings.

The lower bulk density of biochar, along with its ability to increase substrate porosity [68], may improve soil organic matter [68], resulting in increased water retention, more beneficial to plant and microorganism growth [16,47], and provide more host sites for microorganisms [32]. Although we cannot definitively state why gasifier biochar in concert with inoculation yielded the most seedling growth, its initial supply of N (Table 1; [69]) and greater amounts of surface porosity [68] may contribute more desirable refuges for microorganism growth [35] than pyrolytic biochar.

Cultivating container plants for forest restoration activities requires increasing the amounts of soilless media used for production and aggravates environmental concerns about the use of nonrenewable resources [49]. Biochar could be a potential alternative amendment in the growing substrate of container plants because plants with biochar grew similar to (our results), or even better [16,52] than, those without biochar. In addition, inoculation can increase plant growth and the ability of herbal and woody plants to resist stress $[13,25]$. The synergetic effect of rhizobia and biochar on leguminous plants for restoration improves seedling quality and may help land managers achieve specific target plant criteria necessary to overcome environmental limitations on outplanting sites.

Cumulatively, many researchers have demonstrated that rates of biochar from $5 \%$ to $40 \%$ can have positive benefits on seedling quality during nursery production, e.g., $[32,43,49,56]$. Our work presented here also showed that biochar type has a role. Thus, researchers and restoration specialists have a wide palette of potential biochar rates and types that can be combined to meet reforestation challenges identified through the Target Plant Concept. For example, on one hand, a lower rate of biochar along with rhizobia inoculation may be advantageous for leguminous seedlings intended for a low-fertility restoration site because our work shows more BNF with gasifier biochar, and biochar added to soil can improve nutrient availability, e.g., [32,33]. On the other hand, because biochar improves water retention capacity, e.g., [32], a higher rate may be more desired to offset soil water limitations on a droughty site. A high rate may also be desired when carbon sequestration is an objective of site restoration, e.g., [38].

\section{Conclusions}

In summary, we grew black locust seedlings with two different types of biochar (pyrolysis and gasification) and a no-biochar control, with and without inoculation with symbiotic rhizobia, at a robust rate of $\mathrm{N}$ supply. Biochar added at a rate of 5\% (v:v) to a peatmoss medium without inoculation had no effect on seedling growth. Inoculation with rhizobia, independent of biochar, increased growth and seedling $\mathrm{N}$ status, compared to the non-inoculated plants because of increased BNF associated with enhanced nodule development. Combining gasifier biochar and rhizobia inoculation enhanced the growth and $\mathrm{N}$ content of black locust seedlings the most. Our results suggest the potential benefits to seedling quality by matching biochar types to specific restoration species, particularly when the biochar is applied in concert with inoculation of symbiotic microorganisms.

Author Contributions: Q.S. and R.K.D. shared equally in conceiving the research, designing the experiment, interpreting results, and drafting the manuscript. R.K.D. provided research funding and technical expertise during seedling production. Q.S. tended and sampled seedlings. Q.S. performed the data analyses. Y.L. and H.L. revised the manuscript. All authors have read and agreed to the published version of the manuscript.

Funding: This study was funded by USDA Forest Service (USFS) Rocky Mountain Research Station (RMRS), the USFS National Center for Reforestation, Nurseries, and Genetic Resources, and the China Scholarship Funds (No. 201606510045).

Acknowledgments: We thank Thomas Wacek at Plant Probiotics Company for providing rhizobia inoculants, USFS RMRS employees Jeremiah R. Pinto for helping calculate the fertilizer content, Deborah Page-Dumroese for helping collect biochar information, and Charles E. Eckman for helping take care of the seedlings during the research. This research was done when Qiaoyu Sun was as a visiting scholar in Moscow as part of her graduate work at Beijing Forestry University. 
Conflicts of Interest: The authors declare no conflict of interest.

\section{References}

1. Griscom, B.W.; Adams, J.; Ellis, P.W.; Houghton, R.A.; Lomax, G.; Miteva, D.A.; Schlesinger, W.H.; Shoch, D.; Siikamäki, J.V.; Smith, P.; et al. Natural climate solutions. Proc. Natl. Acad. Sci. USA 2017, 114, 11645-11650. [CrossRef] [PubMed]

2. Wolf, C.; Ripple, W.J.; Betts, M.G.; Levi, T.; Peres, C.A. Eating plants and planting forests for the climate. Glob. Chang. Biol. 2019, 25, 3995. [CrossRef] [PubMed]

3. Stanturf, J.A.; Palik, B.; Dumroese, R.K. Contemporary forest restoration: A review emphasizing function. Forest. Ecol. Manag. 2014, 331, 292-323. [CrossRef]

4. Bernal, B.; Murray, L.T.; Pearson, T.R.H. Global carbon dioxide removal rates from forest landscape restoration activities. Carbon Balance Manag. 2018, 13, 22. [CrossRef]

5. Pawson, S.M.; Brin, A.; Brockerhoff, E.G.; Lamb, D.; Payn, T.W.; Paquette, A.; Parrotta, J.A. Plantation forests, climate change and biodiversity. Biodivers. Conserv. 2013, 22, 1203-1227. [CrossRef]

6. Parrotta, J.A.; Wildburger, C.; Mansourian, S. Understanding Relationships between Biodiversity, Carbon, Forests and People: The Key to Achieving REDD+ Objectives; A Global Assessment Report. Prepared by the Global Forest Expert Panel on Biodiversity, Forest Management, and REDD+; International Union of Forest Research Organizations (IUFRO World Series): Vienna, Austria, 2012; Volume 31, 161p.

7. Liang, J.J.; Crowther, T.W.; Picard, N.; Wiser, S.; Zhou, M.; Alberti, G.; Schulze, E.D.; McGuire, D.A.; Bozzato, F.; Pretzsch, H.; et al. Positive biodiversity-productivity relationship predominant in global forests. Science 2016, 354, 196. [CrossRef]

8. Seidl, R.; Thom, D.; Kautz, M.; Martin-Benito, D.; Peltoniemi, M.; Vacchiano, G.; Wild, J.; Ascoli, D.; Petr, M.; Honkaniemi, J.; et al. Forest disturbances under climate change. Nat. Clim. Chang. 2017, 7, 395-402. [CrossRef]

9. Sun, Q.Y.; Dumroese, R.K.; Liu, Y. Container volume and subirrigation schedule influence Quercus variabilis seedling growth and nutrient status in the nursery and field. Scand. J. Forest Res. 2018, 33, 560-567. [CrossRef]

10. Haase, D.L.; Davis, A.S. Developing and supporting quality nursery facilities and staff are necessary to meet global forest and landscape restoration needs. Reforesta 2017, 4, 69-93. [CrossRef]

11. Muller, J.J.; Nagel, L.M.; Palik, B.J. Forest adaptation strategies aimed at climate change: Assessing the performance of future climate-adapted tree species in a northern Minnesota pine ecosystem. Forest. Ecol. Manag. 2019, 451, 1-12. [CrossRef]

12. Oliet, J.A.; Jacobs, D.F. Restoring forests: Advances in techniques and theory. New Forest. 2012, 43, 535-541. [CrossRef]

13. Ferrari, A.E.; Wall, L.G. Nodulation and growth of black locust (Robinia pseudoacacia) on a desurfaced soil inoculated with a local Rhizobium isolate. Biol. Fert. Soils 2007, 43, 471-477. [CrossRef]

14. Mengual, C.M.; Roldán, A.; Caravaca, F.; Schoebitz, M. Advantages of inoculation with immobilised rhizobacteria versus amendment with olive-mill waste in the afforestation of a semiarid area with Pinus halepensis Mill. Ecol. Eng. 2014, 73, 1-8. [CrossRef]

15. Mengual, C.; Schoebitz, M.; Azcón, R.; Roldán, A. Microbial inoculants and organic amendment improves plant establishment and soil rehabilitation under semiarid conditions. J. Environ. Manag. 2014, 134, 1-7. [CrossRef] [PubMed]

16. Ahmad, M.T.; Asghar, H.N.; Saleem, M.; Khan, M.Y.; Zahir, Z.A. Synergistic effect of rhizobia and biochar on growth and physiology of maize. Agron. J. 2015, 107, 2327-2334. [CrossRef]

17. Herrera, M.A.; Salamanca, C.P.; Barea, J.M. Inoculation of woody legumes with selected arbuscular mycorrhizal fungi and rhizobia to recover desertified Mediterranean ecosystems. Appl. Environ. Microb. 1993, 59, 129-133. [CrossRef]

18. Lal, B.; Khanna, S. Long term field study shows increased biomass production in tree legumes inoculated with Rhizobium. Plant Soil 1996, 184, 111-116. [CrossRef]

19. Thrall, P.H.; Millsom, D.A.; Jeavons, A.C.; Waayers, M.; Harvey, G.R.; Bagnall, D.J.; Brockwell, J. Seed inoculation with effective root-nodule bacteria enhances revegetation success. J. Appl. Ecol. 2005, 42, 740-751. [CrossRef]

20. Dumroese, R.K.; Jacobs, D.F.; Davis, A.S. Inoculating Acacia koa with Bradyrhizobium and applying fertilizer in the nursery: Effects on nodule formation and seedling growth. HortScience 2009, 44, 443-446. [CrossRef] 
21. Zhang, P.; Dumroese, R.K.; Pinto, J.R. Organic or inorganic nitrogen and rhizobia inoculation provide synergistic growth response of a leguminous forb and tree. Front. Plant Sci. 2019, 10, 1308. [CrossRef]

22. Diabate, M.; Munive, A.; de Faria, S.M.; Ba, A.; Dreyfus, B.; Galiana, A. Occurrence of nodulation in unexplored leguminous trees native to the West African tropical rainforest and inoculation response of native species useful in reforestation. New Phytol. 2005, 166, 231-239. [CrossRef] [PubMed]

23. Jayakumar, P.; Tan, T.K. Variations in the responses of Acacia mangium to inoculation with different strains of Bradyrhizobium sp. under nursery conditions. Symbiosis 2006, 41, 31-37.

24. Dumroese, R.K.; Landis, T.D.; Pinto, J.R.; Haase, D.L.; Wilkinson, K.M.; Davis, A.S. Meeting forest restoration challenges: Using the Target Plant Concept. Reforesta 2016, 1, 37-52. [CrossRef]

25. Dekak, A.; Chabi, R.; Menasria, T.; Benhizia, Y. Phenotypic characterization of rhizobia nodulating legumes Genista microcephala and Argyrolobium uniflorum growing under arid conditions. J. Adv. Res. 2018, 14, 35-42. [CrossRef]

26. Karthikeyan, A. Effect of arbuscular mycorrhizal fungi and rhizobium on photosynthetic activity and growth response in Acacia auriculiflormis seedlings under elevated $\mathrm{CO}_{2}$. J. Trop. For. Sci. 2019, 31, 398-403. [CrossRef]

27. Kirsten, S.O.; Richard, B.T. Effects of mycorrhizal colonization on biomass production and nitrogen fixation of black locust (Robinia pseudoacacia) seedlings grown under elevated atmospheric carbon dioxide. New Phytol. 1999, 142, 133-140. [CrossRef]

28. Lehmann, J.; Gaunt, J.; Rondon, M. Bio-char sequestration in terrestrial ecosystems-a review. Mitig. Adapt. Strat. Glob. Chang. 2006, 11, 403-427. [CrossRef]

29. Page-Dumroese, D.S.; Coleman, M.; Jones, G.; Venn, T.; Dumroese, R.K.; Anderson, N.; Chung, W.; Loeffler, D.; Archuleta, J.; Kimsey, M.; et al. Portable in-woods pyrolysis: Using forest biomass to reduce forest fuels, increase soil productivity, and sequester carbon. In Proceedings of the 2009 North American Biochar Conference, Boulder, CO, USA, 9-12 August 2009.

30. Xiang, Y.Z.; Deng, Q.; Duan, H.L.; Guo, Y. Effects of biochar application on root traits: A meta-analysis. Glob. Chang. Biol. Bioenergy 2017, 9, 1563-1572. [CrossRef]

31. Dumroese, R.K.; Page-Dumroese, D.S.; Pinto, J.R. Biochar potential to enhance forest resilience, seedling quality, and nursery efficiency. Tree Plant. Notes 2020, 63, 61-69.

32. Heiskanen, J.; Tammeorg, P.; Dumroese, R.K. Growth of Norway spruce seedlings after transplanting into silty soil amended with biochar: A bioassay in a growth chamber. J. For. Sci. 2013, 59, 125-129. [CrossRef]

33. Lehmann, J.; Rillig, M.C.; Thies, J.; Masiello, C.A.; Hockaday, W.C.; Crowley, D. Biochar effects on soil biota-a review. Soil Biol. Biochem. 2011, 43, 1812-1836. [CrossRef]

34. Ishii, T.; Kadoya, K. Effects of charcoal as a soil conditioner on citrus growth and vesicular-arbuscular mycorrhizal development. J. Jpn. Soc. Hortic. Sci. 1994, 63, 529-535. [CrossRef]

35. Rondon, M.A.; Lehmann, J.; Ramírez, J.; Hurtado, M. Biological nitrogen fixation by common beans (Phaseolus vulgaris L.) increases with bio-char additions. Biol. Fert. Soils 2007, 43, 699-708. [CrossRef]

36. Güereña, D.T.; Lehmann, J.; Thies, J.E.; Enders, A.; Karanja, N.; Neufeldt, H. Partitioning the contributions of biochar properties to enhanced biological nitrogen fixation in common bean (Phaseolus vulgaris L.). Biol. Fert. Soils 2015, 51, 479-491. [CrossRef]

37. Van Zwieten, L.; Rose, T.; Herridge, D.; Kimber, S.; Rust, J.; Cowie, A.; Morris, S. Enhanced biological $\mathrm{N}_{2}$ fixation and yield of faba bean (Vicia faba L.) in an acid soil following biochar addition: Dissection of causal mechanisms. Plant Soil 2015, 395, 7-20. [CrossRef]

38. Dumroese, R.K.; Heiskanen, J.; Englund, K.; Tervahauta, A. Pelleted biochar: Chemical and physical properties show potential use as a substrate in container nurseries. Biomass Bioenergy 2011, 35, 2018-2027. [CrossRef]

39. Steiner, C.; Harttung, T. Biochar as a growing media additive and peat substitute. Solid Earth 2014, 5, 995-999. [CrossRef]

40. Conversa, G.; Bonasia, A.; Lazzizera, C.; Elia, A. Influence of biochar, mycorrhizal inoculation, and fertilizer rate on growth and flowering of Pelargonium (Pelargonium zonale L.) plants. Front. Plant Sci. 2015, 6, 429. [CrossRef]

41. Méndez, A.; Paz-Ferreiro, J.; Gil, E.; Gascó, G. The effect of paper sludge and biochar addition on brown peat and coir based growing media properties. Sci. Hortic-Amsterdam. 2015, 193, 225-230. [CrossRef]

42. Di Lonardo, S.; Baronti, S.; Vaccari, F.P.; Albanese, L.; Battista, P.; Miglietta, F.; Bacci, L. Biochar-based nursery substrates: The effect of peat substitution on reduced salinity. Urban For. Urban Gree. 2017, 23, 27-34. [CrossRef] 
43. Matt, C.P.; Keyes, C.R.; Dumroese, R.K. Biochar effects on the nursery propagation of 4 northern rocky mountain native plant species. Native Plants J. 2018, 19, 14-26. [CrossRef]

44. Anderson, N.; Jones, J.G.; Page-Dumroese, D.; McCollum, D.; Baker, S.; Loeffler, D.; Chung, W. A comparison of producer gas, biochar, and activated carbon from two distributed scale thermochemical conversion systems used to process forest biomass. Energies 2013, 6, 164-183. [CrossRef]

45. Kuppusamy, S.; Kumutha, K.; Krishnan, P.S. Influence of biochar and Azospirillum application on the growth of maize. Madras. Agric. J. 2011, 98, 158-164.

46. Hansen, V.; Müller-Stöver, D.; Munkholm, L.J.; Peltre, C.; Petersen, C.; Hauggaard-Nielsen, H.; Jensen, L.S. The effect of straw and wood gasification biochar on carbon sequestration, selected soil fertility indicators and functional groups in soil: An incubation study. Geoderma 2016, 269, 99-107. [CrossRef]

47. Hansen, V.; Hauggaard-Nielsen, H.; Petersen, C.T.; Mikkelsen, T.N.; Müller-Stöver, D. Effects of gasification biochar on plant-available water capacity and plant growth in two contrasting soil types. Soil Till. Res. 2016, 161, 1-9. [CrossRef]

48. Cho, M.S.; Meng, L.; Song, J.H.; Han, S.H.; Bae, K.; Park, B.B. The effects of biochars on the growth of Zelkova serrata seedlings in a containerized seedling production system. For. Sci. Tec. 2017, 13, 25-30. [CrossRef]

49. Dumroese, R.K.; Pinto, J.R.; Heiskanen, J.; Tervahauta, A.; McBurney, K.G.; Page-Dumroese, D.S.; Englund, K. Biochar can be a suitable replacement for sphagnum peat in nursery production of Pinus ponderosa seedlings. Forests 2018, 9, 232. [CrossRef]

50. Sarauer, J.L.; Coleman, M.D. Biochar as a growing media component for containerized production of Douglas-fir. Can. J. For. Res. 2018, 48, 581-588. [CrossRef]

51. Ge, X.G.; Yang, Z.Y.; Zhou, B.Z.; Cao, Y.H.; Xiao, W.F.; Wang, X.M.; Li, M.H. Biochar fertilization significantly increases nutrient levels in plants and soil but has no effect on biomass of Pinus massoniana (Lamb.) and Cunninghamia lanceolata (Lamb.) Hook. saplings during the first growing season. Forests 2019, 10, 612. [CrossRef]

52. Yusif, S.A.; Muhammad, I.; Hayatu, N.G.; Sauwa, M.M.; Tafinta, I.Y.; Mohammed, M.A.; Lukman, S.A.; Abubakar, G.A.; Hussain, A.M. Effects of biochar and rhizobium inoculation on nodulation and growth of groundnut in Sokoto State, Nigeria. J. Appl. Life Sci. Int. 2016, 9, 1-9. [CrossRef]

53. Olson, D.F., Jr.; Karrfalt, R.P. Robinia L. Black locust. In The Woody Plant Seed Manual; Agriculture Handbook 727; Bonner, F., Karrfalt, R.P., Eds.; USDA Forest Service: Washington, DC, USA, 2008.

54. Keresztesi, B. The Black Locust. Unasylva 1980, 32, 23-33.

55. Roberts, D.R.; Zimmerman, R.W.; Stringer, J.W.; Carpenter, S.B. The effects of combined nitrogen on growth, nodulation, and nitrogen fixation of black locust seedlings. Can. J. For. Res. 1983, 13, 1251-1254. [CrossRef]

56. Vaughn, S.F.; Kenar, J.A.; Thompson, A.R.; Peterson, S.C. Comparison of biochars derived from wood pellets and pelletized wheat straw as replacements for peat in potting substrates. Ind. Crop. Prod. 2013, 51, 437-443. [CrossRef]

57. Dumroese, R.K.; Montville, M.E.; Pinto, J.R. Using container weights to determine irrigation needs: A simple method. Nativ. Plants J. 2015, 16, 67-71. [CrossRef]

58. Hardarson, G.; Danso, S.K.A. Methods for measuring biological nitrogen fixation in grain legumes. Plant Soil 1993, 152, 19-23. [CrossRef]

59. Egamberdieva, D.; Wirth, S.; Behrendt, U.; Abd_Allah, E.F.; Berg, G. Biochar treatment resulted in a combined effect on soybean growth promotion and a shift in plant growth promoting rhizobacteria. Front. Microbiol. 2016, 7, 209. [CrossRef]

60. Nelson, N.O.; Agudelo, S.C.; Yuan, W.Q.; Gan, J. Nitrogen and phosphorus availability in biochar-amended soils. Soil Sci. 2011, 176, 218-226. [CrossRef]

61. Brewer, C.E. Biochar Characterization and Engineering. Graduate Thesis and Dissertations, Iowa State University, Ames, IA, USA, 2012.

62. Zwart, D.C.; Kim, S.H. Biochar amendment increases resistance to stem lesions caused by Phytophthora spp. in tree seedlings. HortScience 2012, 47, 1736-1740. [CrossRef]

63. Mehboob, I.; Zahir, Z.A.; Arshad, M.; Tanveer, A.; Farooq-e-Azam. Growth promoting activities of different Rhizobium spp. in wheat. Pak. J. Bot. 2011, 43, 1643-1650.

64. Boddey, R.M.; Urquiaga, S.; Neves, M.C.P.; Suhet, A.R.; Peres, J.R. Quantification of the contribution of $\mathrm{N}_{2}$ fixation to field-grown grain legumes-a strategy for the practical application of the ${ }^{15} \mathrm{~N}$ isotope dilution technique. Soil Biol. Biochem. 1990, 22, 649-655. [CrossRef] 
65. Billah, M.M.; Ahmad, W.; Ali, M. Biochar particle size and rhizobia strains effect on the uptake and efficiency of nitrogen in lentils. J. Plant Nutri. 2019, 42, 1709-1725. [CrossRef]

66. Iijima, M.; Yamane, K.; Izumi, Y.; Daimon, H.; Motonaga, T. Continuous application of biochar inoculated with root nodule bacteria to subsoil enhances yield of soybean by the nodulation control using crack fertilization technique. Plant Prod. Sci. 2015, 18, 197-208. [CrossRef]

67. Budi, S.W.; Setyaningsih, L. Arbuscular mycorrhizal fungi and biochar improved early growth of neem (Melia azedarach Linn.) seedling under greenhouse conditions. J. Manajemen Hutan Tropika 2013, 19, 103-110. [CrossRef]

68. Yang, X.; Tsibart, A.; Nam, H.; Hure, J.; El-Naggar, A.; Tackc, F.M.G.; Wang, C.H.; Lee, Y.H.; Tsang, D.C.W.; Ok, Y.S. Effect of gasification biochar application on soil quality: Trace metal behavior, microbial community, and soil dissolved organic matter. J. Hazard. Mater. 2019, 365, 684-694. [CrossRef] [PubMed]

69. Jeffery, A.; Verheijen, F.G.A.; van der Velde, M.; Bastos, A.C. A quantitative review of the effects of biochar application to soils on crop productivity using meta-analysis. Agr. Ecosyst. Environ. 2011, 144, 175-187. [CrossRef]

(C) 2020 by the authors. Licensee MDPI, Basel, Switzerland. This article is an open access article distributed under the terms and conditions of the Creative Commons Attribution (CC BY) license (http://creativecommons.org/licenses/by/4.0/). 